\title{
EFFECT OF ORGANIC LOAD AND ALKALINITY ON DAIRY WASTEWATER BIOMETHANATION
}

Doi:http://dx.doi.org/10.1590/1809-4430-Eng.Agric.v37n4p820-827/2017

\section{EDUARDO M. KISPERGHER ${ }^{1 *}$, CAMILA A. D'AQUINO², LUIS C. DA COSTA JUNIOR ${ }^{2}$, THIAGO C. DE MELLO ${ }^{2}$, REGINA WEINSCHUTZ ${ }^{3}$, ALVARO L. MATHIAS ${ }^{3}$}

${ }^{1 *}$ Corresponding author. Secretaria de Estado de Saúde do Acre/ Rio Branco - AC, Brasil. E-mail: e.kispergher@gmail.com

\begin{abstract}
This study aimed to evaluate the effect of variations in organic load (hydraulic retention times - HRTs: from 2 to 0.5 day) and in alkalinity $\left(\mathrm{NaHCO}_{3}\right.$ from 4,000 to 1,000 mg.L $\left.\mathrm{L}^{-1}\right)$ on methane production. Biomass of sewage sludge was inoculated and stabilized on 1" polypropylene rings. The rings were immersed in the liquid phase $(8.41 \mathrm{~L})$ of an upflow anaerobic filter reactor $(12.22 \mathrm{~L})$. A solution of $5 \mathrm{~g}$ of whole milk powder per liter was used to simulate effluent from the dairy industry. Process effectiveness was measured by chemical oxygen demand reduction, biogas production, and biogas methane content. Biogas production started at a 2-day HRT and synthetic effluent alkalinization with 4,000 mg. $\mathrm{L}^{-1} \mathrm{NaHCO}_{3}$. The best operation condition was at 1-day HRT and with the addition of 4,000 mg.L $\mathrm{L}^{-1} \mathrm{NaHCO}_{3}$. Biogas production reached 1.5 NL of biogas per L of reactor liquid phase, with $68 \%$ of methane and a concomitant reduction in COD of $57 \%$.
\end{abstract}

KEYWORDS: dairy industry, biofilter, hydraulic retention time, alkalinity, biogas.

\section{INTRODUCTION}

In 2015, Brazilian milk production was estimated at 37.2 billion liters (MAPA, 2015) and worldwide production at 830 billion liters (FAO, 2015). Daily processing of dairy products generates a large quantity of wastewater with a high organic load. Therefore, the environmental impact of this waste can be quite significant, whether due to a large flow or high treatment costs involved (Omil, 2013).

The effluents from cheese factories can be divided into two basic categories: washing and pasteurization waters (low chemical oxygen demand - COD) and cheese whey (high COD, up to $50,000 \mathrm{mg} . \mathrm{L}^{-1}$ ) (Chatzipaschali \& Stamatis, 2012). Generally, the chemical oxygen demand (COD) levels of dairy wastewaters vary between 1,150 and 9,200 mg COD.L ${ }^{-1}$ (Demirel et al, 2005).

Wastewaters with these characteristics can be bio-transformed through aerobic and/or anaerobic processes to reduce the organic load. Compared to the aerobic, the anaerobic process is simpler and has lower operating costs, besides being more energy-efficient (Patel et al, 1999), producing less sludge, requiring less inorganic nutrients, and generating methane as a by-product (Patil et al, 2012).

Since the eighties, the anaerobic digestion has developed facing some bottlenecks of small and medium industries such as excessive sludge production, energy requirements, and solids settling when applying aerobic processes (Prazeres et al., 2012). Despite these advantages, anaerobic digestion has not been well established as a treatment method for dairy effluents. This is because of the low conversion rates required by long hydraulic retention times (HRT) and the low process stability (Gannoun et al, 2008).

The growing demand and cost of energy in recent years changed this scenario, and there has been a considerable attention paid to improving fermenters for biogas production, especially highrate reactors, such as fixed-bed reactors, for the treatment of organic effluents (Oliveira \& Bruno, 2013). The upflow anaerobic filter with low HRT is a compact treatment unit, and has been

\footnotetext{
${ }^{2}$ Institutos LACTEC/ Curitiba - PR, Brasil.

${ }^{3}$ Universidade Federal Do Paraná/Curitiba - PR, Brasil.

Received in: 3-9-2016

Accepted in: 3-26-2017
} 
recommended for the treatment of dairy product wastewater, due to its low content of fixed solids in the effluent, which prevents clogging and the creation of preferential paths. An anaerobic filter of 1

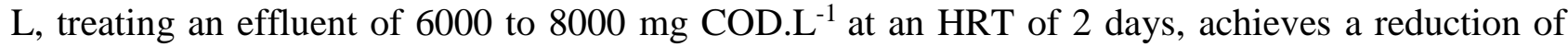
$75 \%$ COD with the production of $3.3 \mathrm{~L}$ of biogas. $\mathrm{L}^{-1}$ reactor.day ${ }^{-1}$ (Patel et al,1999). Also, the biogas produced by the anaerobic digestion of industrial wastewater can be exploited as an alternative energy source. The energy potential of $1 \mathrm{Nm}^{3}$ of biogas composed of $65 \%$ methane is equivalent to $3.47 \mathrm{~kg}$ of wood, $0.63 \mathrm{~L}$ of kerosene, $0.61 \mathrm{~L}$ of diesel oil, and $1.25 \mathrm{kWh}$ of electricity (Oliveira et al, 2011).

However, despite the high efficiency of COD removal, the low alkalinity of industrial waste (expressed by carbonate ion content), sometimes as low as 50 meq. $\mathrm{L}^{-1}$, can impair the efficiency of fermentation for methane production (Prazeres et al, 2012). In this case, alkaline supplementation is necessary to maintain a continuous biomethanation. The addition of an alkaline agent to the effluent, such as sodium bicarbonate, sodium hydroxide, calcium hydroxide, or lime, is recommended. Alternatively, recirculation of part of the liquid phase has also been described to increase alkalinity and dilute the content of organic matter in the substrate at bioreactor entrance (Zhou et al, 2011).

The objective of this study was to evaluate the influence of organic load, by changing the HRT, and the influence of alkalinity, varying sodium bicarbonate supplementation, on the production of methane from dairy industry wastewater using an upflow anaerobic filter reactor.

\section{MATERIAL AND METHODS}

Effluent was sampled from a dairy industry located near Ponta Grossa (Paraná, Brazil) and analyzed to determine the real values of COD (method 5220 D; APHA, 2012), pH (bench top pH meter from Hanna Instruments HI2221; Romania), alkalinity (method 2320 B; APHA, 2012), and volatile solids (VS, method 2540E; APHA, 2012). Biogas volume and composition were analyzed during fermentation. The biogas volume was measured with a device developed by LACTEC (Institute of Technology for the Development of Paraná - Curitiba - Paraná - Brazil). The gas exited the bioreactor through a system of communicating vessels (Fig 1) to be fed into a gas-liquid separator, at a pressure slightly higher than atmospheric. The gas filled in a bag (gasometer) was slowly released into the lower part of a shell-shaped apparatus, which were kept submerged under water. Gas accumulation at specific volume caused a thrust force that lifted the shell, releasing gas. This vertical movement generated an electrical signal that was recorded on a personal computer running under LabVIEW platform (National Instruments, USA). In this way, a direct correlation was established between the electric signals and the produced biogas volume. The biogas volume was measured at laboratory conditions $(296.15 \mathrm{~K}$; 91,200 Pa) and then normalized to $(273.15 \mathrm{~K}$; $101,325 \mathrm{~Pa}$ ). The biogas chemical composition was determined in a Trace GC (Thermo Finnigan, USA) gas chromatograph equipped with three columns [Petrocol DH 150 (150 m x $0.25 \mathrm{~mm}$ ), DC $200(1.8 \mathrm{~m})$, and Porapak-N (2.0 $\mathrm{m} \mathrm{x} \mathrm{1/8")].} \mathrm{A} \mathrm{bioreactor} \mathrm{gas} \mathrm{sample} \mathrm{was} \mathrm{taken} \mathrm{by} \mathrm{using} \mathrm{a} \mathrm{plastic}$ syringe, being manually injected into the gas chromatograph. Nitrogen was used as the gas carrier to conduct the sample to flame ionization (FID) and thermal conductivity (TCD) detectors for biogas qualitative and quantitative evaluations. 


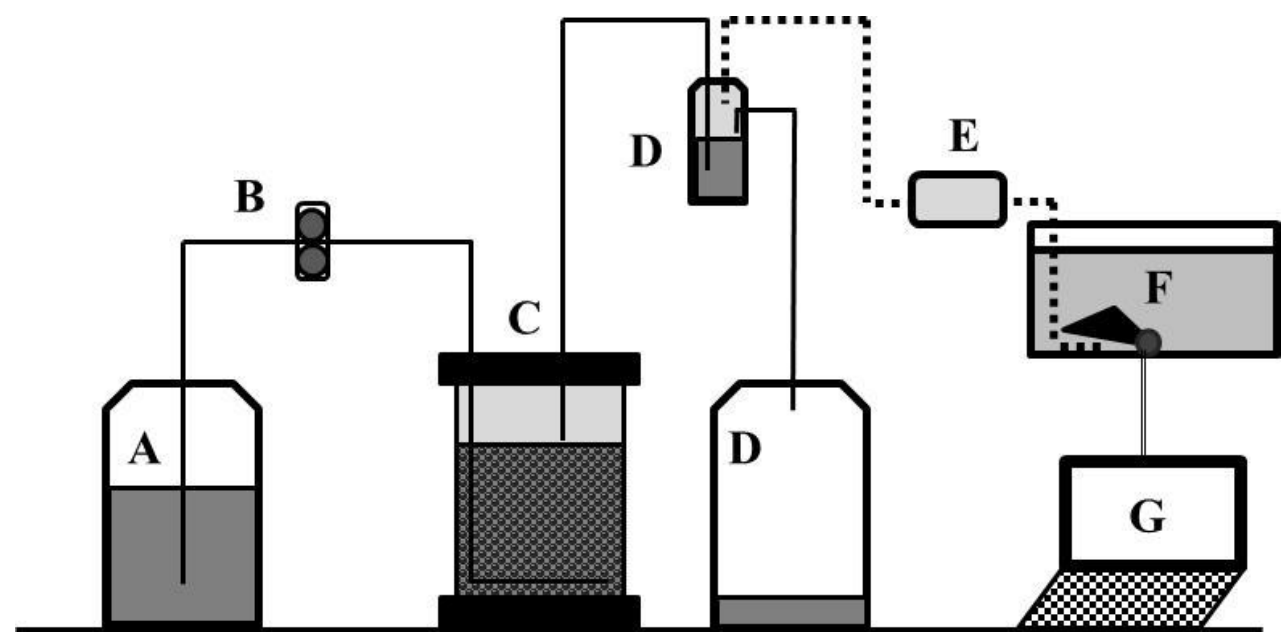

FIGURE 1. Diagram of the experimental apparatus: A) vessel with SIE; B) peristaltic pump; C) bioreactor; D) gas liquid separator and treated effluent vessel; E) biogas bag; F) biogas meter, and G) computer.

\section{Synthetic industrial effluent}

Dairy wastewater results from cleaning transport lines and tanks or operation errors (Demirel, et al, 2005), producing highly diluted milk solutions. A synthetic industrial effluent (SIE) was produced based on industrial wastewater parameters, such as $\mathrm{COD}, \mathrm{pH}, \mathrm{VS}$, and alkalinity, being used as a nutrient (substrate) in the bioreactor. The use of a SIE eliminates variations in substrate composition, whether due to variations in industrial process or microbiota variability. Thus, a solution of $5,000 \mathrm{mg} \cdot \mathrm{L}^{-1}$ of powdered milk was prepared and used immediately in the experiments, after SIE being alkalized with 4,000 mg.. ${ }^{-1}$ of sodium bicarbonate.

\section{Bioreactor inoculation}

Part of the volume $(8.41 \mathrm{~L})$ of an upflow anaerobic filter fermenter $(12.22 \mathrm{~L})$ was filled with 1-inch polypropylene rings (HyFlow Pall Rings, Interpaking, Brazil). These rings were previously inoculated with sludge from upflow anaerobic sludge blanket (UASB) reactors from the sewage treatment plant of Atuba Sul, in Curitiba - Paraná (Brazil). In doing so, these plastic rings were placed in a tray, submerged in sludge, and then kept static in an incubator at $45^{\circ} \mathrm{C}$ for seven days. Afterwards, they were randomly placed into the bioreactor and fed with a synthetic sewage effluent - SSE (Cubas et al, 2011), simulating a domestic sewage with a low organic load. It was injected at a flow of $3 \mathrm{~mL} \cdot \mathrm{min}^{-1}$ to keep the biosystem active and stabilized.

\section{Bioreactor operation}

Methane production capacity was assessed by using SIE at $35 \pm 2{ }^{\circ} \mathrm{C}$ with four different HRTs (Table 1). Bioreactor temperature was maintained constant using an electronic heat belt (Higher HRCT 19-L-P $300 \mathrm{~W}$, Brazil), and thermal insulation assured by a one-inch-thick stone wool blanket (Rockbras, Brazil). The reactor was continuously fed with the SIE through a peristaltic pump (Watson Marlow 520U, England) for seven days to replace the SSE and adapt the system (Table 1 , conditions 0 and 1 respectively). The SIE (5 g powdered whole milk. $\left.\mathrm{L}^{-1}\right)$ received an addition of 4,000 mg. $\mathrm{L}^{-1}$ of sodium bicarbonate, and fermentation was performed with different HRTs, being gradually reduced from 2.0 to 0.5 days for HRT effect evaluation (Table 1, conditions 2 to 5). The criterion for HRT change was biogas production stabilization $( \pm 10 \%)$ and $\mathrm{pH}$ responses $( \pm 0.2 \%) . \mathrm{NaHCO}_{3}$ supplemented $\mathrm{SIE}$, with an HRT of 1 day, was used to determine the ideal alkaline supplementation (Table 1, conditions 6 to 9). In this case, bicarbonate concentration was reduced stepwise from 4,000 to 1,000 mg. $\mathrm{L}^{-1}$ so its influence on gas production and on effluent $\mathrm{pH}$ could be measured. Again, biogas production stabilization $( \pm 10 \%)$ and $\mathrm{pH}$ responses $( \pm 0.2 \%)$ were the criteria for salt concentration changes. 
TABLE 1. Experiment design.

\begin{tabular}{llll}
\hline Condition & HRT (day) & $\mathrm{NaHCO}_{3}\left(\mathrm{mg} . \mathrm{L}^{-1}\right)$ & Days at the condition \\
\hline 0 (SSE)* & 2.0 & $0^{*}$ & $0-2^{* *}$ \\
1 & 2.0 & 0 & $2-9$ \\
2 & 2.0 & 4000 & $9-38$ \\
3 & 1.5 & 4000 & $38-63$ \\
4 & 1.0 & 4000 & $63-98$ \\
5 & 0.5 & 4000 & $98-122$ \\
6 & 1.0 & 4000 & $122-140$ \\
7 & 1.0 & 3000 & $140-151$ \\
8 & 1.0 & 2000 & $151-171$ \\
9 & 1.0 & 1000 & $171-181$ \\
\hline
\end{tabular}

*initial situation $=$ the bioreactor was fed with SSE for biofilm maintenance and stabilization of the controlled culture medium (Cubas et al, 2011). ${ }^{* *}$ A 2-day HRT was assumed as sufficient so that all the fermenter fluid is fully replaced with the SIE.

\section{RESULTS AND DISCUSSION}

\section{Fermentation of the synthetic effluent}

Sewage sludge was an adequate source of microorganisms for the creation of a biologically fixed bed. It is worth mention that the biologic bed remained active for 6 months, based on biogas production and COD reduction. The SIE (COD 7,839 mg.L $\mathrm{L}^{-1}$; $\mathrm{pH}$ 6.2; alkalinity $150 \mathrm{mg} \mathrm{CaCO} \cdot \mathrm{L}^{-1}$; VS $0.47 \%$ ) proved to be similar to the real industrial effluent (COD 8,510 mg.L $\mathrm{L}^{-1}$; pH 6.3 ; alkalinity $0 \mathrm{mg} \mathrm{CaCO} 3 . \mathrm{L}^{-1}$; VS $\left.0.65 \%\right)$. The effluent $\mathrm{pH}$ exiting the bioreactor $\left(\mathrm{pH}_{\mathrm{out}}\right)$ was daily measured since methanogens are highly sensitive to this parameter (Pontoni et al, 2015). In a few days, SIE fermentation without bicarbonate supplementation (initial $\mathrm{pH}$ of 6.2; condition 1, Table 1) showed a marked drop in $\mathrm{pH}_{\text {out }}$ (from 6.5 to less than 5.5). However, this $\mathrm{pH}$ is insufficient to methane production, as confirmed through biogas production observations. Yet alkalinity increased from 150 $\mathrm{mg} \mathrm{CaCO}_{3} \cdot \mathrm{L}^{-1}$ to $1,260 \mathrm{mg} \mathrm{CaCO} 3 . \mathrm{L}^{-1}\left(10^{\text {th }}\right.$ day). This increase was probably due to the byproducts from hydrolysis of macromolecules. For example, the amino acids from protein degradation contain a carboxylic group (acid) and an amine group (base) which are able to buffer the $\mathrm{pH}$ to near 5 (Fennema et al., 2010). According to Tauseef et al (2013), the recommended alkalinity for biomethanation is between 2,500 and 4,500 $\mathrm{mg} \mathrm{CaCO}_{3} \cdot \mathrm{L}^{-1}$.

\section{Effect of TRH on fermentation of the alkalinized SIE}

From the ninth day on (condition 2 in Table 1), 4,000 mg of $\mathrm{NaHCO}_{3} \cdot \mathrm{L}^{-1}$ was added to the SIE in order to increase alkalinity (from 150 to $\left.2,350 \mathrm{mg} \mathrm{CaCO}_{3} \cdot \mathrm{L}^{-1}\right)$. COD $\left(7,839 \mathrm{mg} \cdot \mathrm{L}^{-1}\right.$ ) had no alteration but $\mathrm{pH}$ was significantly increased at the reactor entrance (from 6.2 to 8.1). The $\mathrm{pH}_{\text {out }}$ also increased, reaching 7.05 on the $14^{\text {th }}$ day and remaining at $7.00 \pm 0.40$ from then on. This suggests that the bicarbonate is able to form a stable buffered system, and its alkalinizing capacity is not completely consumed even with the production of acids during the acidogenic phase.

There is a direct relationship between COD and volatile solids in organic matter (Harnadek et al., 2015) and, apparently, dairy wastewater biodegradability is not an issue. Gannoun et al. (2008) reported $90.2 \%$ organic load removal efficiency by treating cheese whey with 5,000 mg COD.L ${ }^{-1}$ and an HRT of 4 days. However, in the present study, the mean VS removal was $46.7 \%$, with a maximum of $55.5 \%$ (Table 2), at an HRT of 2 days, despite the extremely low production of biogas in some cases. This shows that VS biodegradability may be high, but it is not necessarily achieved with methane coproduction. The hydraulic flow distribution through the filter-type fermenter has been reported as a very important parameter for its optimization. This was confirmed by altering the operating conditions from $2(\mathrm{HRT}=2$ days) to $4(\mathrm{HRT}=1$, Table 1$)$, which resulted in a significant reduction in COD (57\% at condition 4; Table 2). This behavior change may be attributed to the upflow turbulence increase. Thus, an even better transfer of matter can take place, which is critical in treatments of high organic loading rate to ensure a high transfer efficiency of heat and matter 
between the biomass and the substrate, and to maintain uniform distribution of substrates and fermentation products, preventing microbial physiological stress (Goyal et al, 1996). In this case, an excessive upflow turbulence, under operation condition 5 (HRT $=0.5$ days, Table 1 ), seemed to drag part of the activated sludge off the filling rings. As a result, the flocs no longer degraded the effluent efficiently but became part of the effluent from the reactor, i.e., the yield of COD removal $\left(\mathrm{COD}_{\text {rem }}=20.8 \%\right)$ was reduced.

TABLE 2. Effect of the HRT on the principal characteristics of the effluent.

\begin{tabular}{|c|c|c|c|c|c|c|c|}
\hline 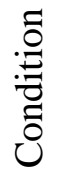 & $\mathrm{pH}_{\text {out }}$ & $\mathrm{VS}_{\text {rem }}$ & $\mathrm{COD}_{\mathrm{rem}} *$ & $\begin{array}{c}\mathrm{V}_{\text {biogas }}{ }^{*} \\
\left(\mathrm{NL}^{- \text {day }^{-1}}\right)\end{array}$ & Methane content & $\mathrm{V}_{\mathrm{b}} / \mathrm{V}_{\mathrm{f}}$ & $\mathrm{V}_{\mathrm{met}} / \mathrm{COD}_{\mathrm{rem}}$ \\
\hline & $7.00(0.40)$ & $55.5 \%$ & $36.99 \%$ & $0.84(0.11)$ & $72 \%$ & \multirow{3}{*}{$\begin{array}{l}0.10 \\
0.30 \\
1.37\end{array}$} & 0.05 \\
\hline & $7.00(0.40)$ & $33.5 \%$ & $41.87 \%$ & $2.45(0.68)$ & $60 \%$ & & 0.08 \\
\hline & $7.00(0.40)$ & $51.9 \%$ & $56.62 \%$ & $11.52(1.83)$ & $68 \%$ & & 0.21 \\
\hline & $7.00(0.40)$ & $45.9 \%$ & $26.01 \%$ & $10.91(1.07)$ & $56 \%$ & 1.30 & 0.18 \\
\hline & $7.25(0.13)$ & N.A & $40.66 \%$ & $8.04(1.17)$ & $61 \%$ & 0.96 & 0.18 \\
\hline & 7.08(0.09) & N.A & $46.50 \%$ & $7.55(0.21)$ & $57 \%$ & 0.90 & 0.14 \\
\hline & $6.95(0.19)$ & N.A & $24.01 \%$ & $6.27(0.71)$ & $56 \%$ & 0.75 & 0.22 \\
\hline & $6.32(0.12)$ & N.A & $49.47 \%$ & $5.39(0.24)$ & $62 \%$ & 0.64 & 0.10 \\
\hline
\end{tabular}

*Mean value (standard deviation); $\mathrm{COD}_{\text {rem }}=$ chemical oxygen demand $\left(\mathrm{mg} . \mathrm{L}^{-1}\right) ; \mathrm{VS}_{\text {rem }}=$ volatile solids removed; $\mathrm{V}_{\text {biogas }}=$ biogas volume $\left(\mathrm{NL} . \mathrm{day}^{-1}\right) ; \mathrm{Vb} / \mathrm{Vf}=\mathrm{V}_{\text {biogas. }} . \mathrm{V}_{\text {reactor }}{ }^{-1} ; \mathrm{V}_{\text {met }} / \mathrm{COD}_{\text {rem }}=\mathrm{NL} \mathrm{CH}_{4} \cdot \mathrm{g} \mathrm{COD}_{\text {rem }}{ }^{-1}$

COD removal yield reached $56.6 \%$ when the filter was operated with an HRT of 1.0 day (condition 4, Table 1). This condition also yielded the highest biogas production (11.52 NL.day ${ }^{-1}$ ) and methane content $\left(68 \%\right.$, Table 2). Even so, the $\mathrm{COD}_{\text {rem }}$ was lesser than that reported for cheese whey treatment with an initial COD of $30,000 \mathrm{mg} . \mathrm{L}^{-1}$, fermented in an anaerobic filter at $40^{\circ} \mathrm{C}$ with an HRT of 2 days; this process achieved levels of organic load removal and methane content of $74.5 \%$ and 69\%, respectively (Patel et al, 1999). This reaffirms that an anaerobic filter reactor has great potential for wastewater treatment, as long as alkalinity is controlled.

Biogas production (Fig 2) is an efficiency parameter of anaerobic methanogenic degradation. The highest biogas production occurred at condition $4\left(\mathrm{HRT}=1.0\right.$ day and 4,000 $\mathrm{mg} \mathrm{NaHCO} \cdot \mathrm{L}^{-1}$, Table 1) which, under normal conditions, also corresponded to a higher ratio of methane volume per gram of COD removed (0.21 NL CH4.g COD $\mathrm{rem}^{-1}$, Table 2). The biogas had high methane content, between 56 and 72\%, regardless of the HRT value (Table 2). According to Chatzipaschali \& Stamatis (2012), 55\% of methane content is expected in biogas from cheese whey anaerobic digestion. One cubic meter of methane represents 10.4 KWh (Luste et al, 2012). As stated, there was no visible change in the biomass layer, neither during fermenter stabilization with SSE nor during the entire study with SIE. However, the methane volume versus COD $_{\text {rem }}$ (Table 2) was lower for the HRT of 2 days $\left(\mathrm{V}_{\mathrm{CH} 3} . \mathrm{g} \mathrm{COD}_{\mathrm{rem}^{-1}}=0.05\right)$ and 1.5 days $\left(\mathrm{V}_{\mathrm{CH} 3 . \mathrm{g}} \mathrm{CDO}_{\mathrm{rem}^{-1}}{ }^{-1}=0.08\right)$ than was in the best condition (HRT 1, $\mathrm{V}_{\mathrm{CH} 3} . \mathrm{g} \mathrm{CDO}_{\mathrm{rem}^{-1}}=0.21$ ), suggesting that part of the organic matter may have been converted to biomass. The biogas volume versus reactor volume ratio is 1.37 NLbiogas. Lreactor $^{-1}$ for the HRT of 1 day, which is a relevant aspect of the study and designing of this equipment. Gannoun et al. (2008), when treating effluents from cheese production with COD of 5,000 mg.L $\mathrm{L}^{-1}$ and HRT between 1 and 4 days reported similar behavior. These authors observed that the greatest biogas volume occurred with an HRT of 2 days, reaching a relative biogas production of $0.280 \mathrm{~L} \mathrm{CH}_{4} . \mathrm{g} \mathrm{COD}_{\text {rem }}{ }^{-1}$. The theoretical biochemical methane potential per gram of $\mathrm{COD}_{\text {rem }}$ is $0.350 \mathrm{~L}$ (Prabhudessai et al, 2013). However, some organic matter is used for growth of microorganisms and maintenance of cellular metabolism (Raposo et al, 2011). 


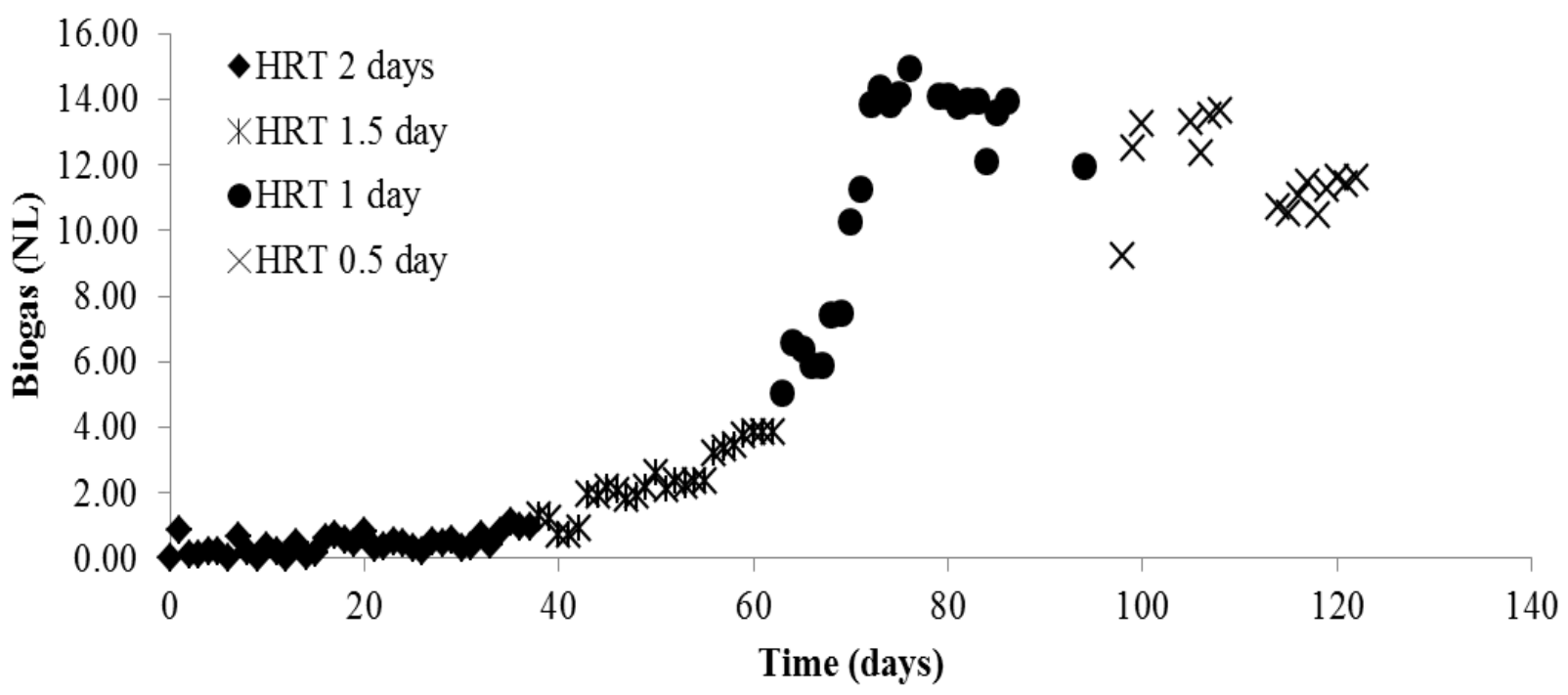

FIGURE 2. Effect of the HRT on the production of biogas (NL).

\section{Effect of an alkalinizing agent on synthetic effluent fermentation}

Alkaline solutions neutralize the volatile fatty acids produced during the acidogenic phase of an anaerobic fermentation (Deublein \& Steinhauser, 2011). Under condition 4 (HRT $=1$ day, Table 1), the bioreactor achieved the highest COD removal efficiency; yielding higher daily biogas production and higher methane content (Table 2). Thus, an HRT of 1 day was used to evaluate the effect of sodium bicarbonate supply reduction. The alkalization power of each gram of sodium bicarbonate was measured as $627.5 \mathrm{mg} \mathrm{CaCO} 3 \cdot \mathrm{L}^{-1} \cdot \mathrm{g}^{-1}$. A reduction of the salt supplementation resulted in a drop of $\mathrm{pH}_{\text {out }}$ and, consequently, a reduction of biogas production (Fig 3). It is a known fact that $\mathrm{pH}_{\text {out }}$ decrease and biogas $\mathrm{CO}_{2}$ content increase indicate a system disturbance (Deublein \& Steinhauser, 2011); however, a higher $\mathrm{CO}_{2}$ production has not been confirmed based on methane content (Table 2).

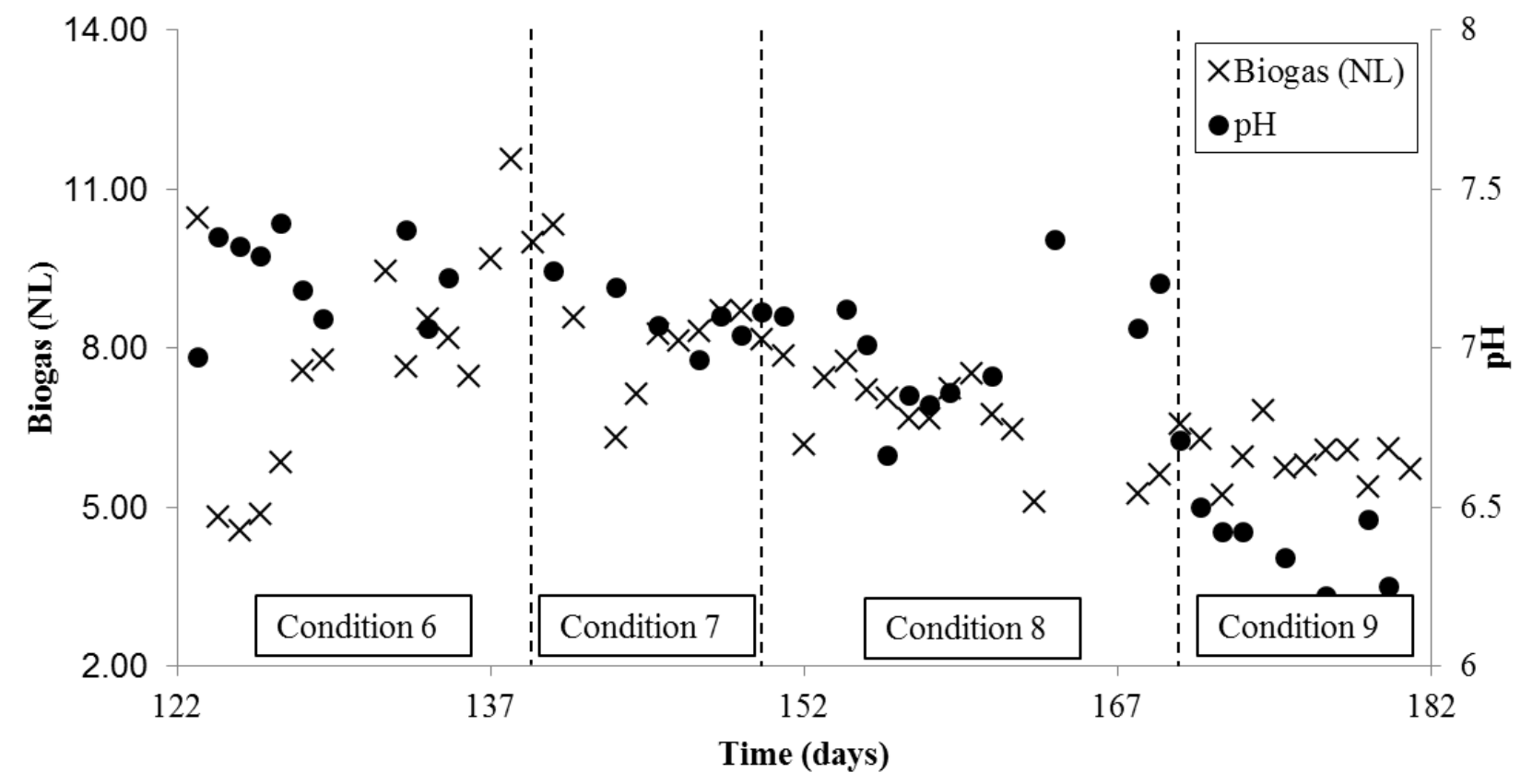

FIGURE 3. Effect of alkali agent concentration on $\mathrm{pH}_{\text {out }}$ and biogas volume during fermentation 


\section{CONCLUSIONS}

Sewage sludge can be used as a source of microorganisms for production of a biofilm in 1" polypropylene rings used for filling an upflow anaerobic filter reactor. The biological bed remained active for almost 6 months without any significant disturbance, even when operated under different conditions. The dairy industry produces a high organic content with low $\mathrm{pH}$. Methane was not produced without an alkaline agent. Sodium bicarbonate is a good alkalizing agent; however, an economic analysis is mandatory before starting this operation. The volume of methane produced may not be able to cover the cost of this additive. Hydraulic retention time is a critical parameter on methane production and is specific for each type of bioreactor. In this study, the highest capacity to reduce COD $(56.6 \%)$ of the alkalinized effluent, and the highest production of biogas (1.37 $\mathrm{NL}_{\text {biogas. }}$ Lreactor $^{-1}$ ), were both achieved with an HRT of 1 day and alkalinization with 4,000 mg $\mathrm{NaHCO}_{3} \cdot \mathrm{L}^{-1}$, corresponding to a conversion of $0.21 \mathrm{NL} \mathrm{CH}_{4} . \mathrm{g} \mathrm{DQO} \mathrm{Pem}^{-1}$. The alkali agent may be reduced to $3,000 \mathrm{mg} \mathrm{NaHCO}_{3}{ }^{-1} \cdot \mathrm{L}^{-1}$, with a slight decrease in the biogas production.

\section{ACKNOWLEDGEMENTS}

The author thanks the Universidade Federal do Paraná - UFPR (Federal University of Paraná State), the Conselho Nacional de Desenvolvimento Científico e Tecnológico - CNPq (National Council for Scientific and Technological Development), the Coordenação de Aperfeiçoamento Pessoal de Nível Superior - CAPES/ REUNI (Coordination of Personnel Improvement for the Higher Education) for the financial support, and the LACTEC company for technical support and partnership.

\section{REFERENCES}

Chatzipaschali AA, Stamatis AG (2012) Biotechnological utilization with a focus on anaerobic treatment of cheese whey: current status and prospects. Energies 5:3492-525. Available: www.mdpi.com/journal/energies. Accessed: Feb 15, 2016.

Cubas SA, Foresti E, Roddrigues JAD, Ratusznei SM, Zaiat M (2011) Effect of impeller type and stirring frequency on the behavior of an ANSBBR in the Treatment of low-strength wastewater. Bioresource Technology 102(2):889-893.

Demirel B, Yenigun O, Onay TT (2005) Anaerobic treatment of dairy wastewaters: a review. Process Biochemistry 40(8):2583-2595.

Deublein D, Steinhauser A (2011) Biogas from waste and renewable resources: an introduction. Weinhein, Ed. Wiley-Vch. 443p.

FAO - Food and Agriculture Organization of the United Nations (2015) Food Outlook: biannual report on global food markets. Rome, FAO. 142p.

Fennema OR, Damodaran S, Parkin KL (2010) Fennema food chemistry. Porto Alegre, Artmed. 900p.

Gannoun H, Khelifi E, Bouallagui H, Touhami Y, Hamdi M (2008) Ecological clarification of cheese whey prior to anaerobic digestion in upflow anaerobic filter. Bioresource Technology 99(14):6105-6111.

Goyal SK, Seth R, Handa BK (1996) Diphasic fixed-film biomethanation of distillery spentwash. Bioresource Technology 56(2-3):239-244.

Harnadek CMW, Guilford NGH, Edwards EA (2015) Chemical oxygen demand analysis of anaerobic digester contents. STEM Fellowship Journal 1(2):2-5.

Luste S, Heinonen-Tanski H, Luostarinen S (2012) Co-digestion of dairy cattle slurry and industrial meat-processing by-products - effect of ultrasound and hygienization pre-treatments. Bioresource Technology 104:195-201. 
MAPA - Ministério da Agricultura, Pecuária e Abastecimento (2015) Agribusiness projections: Brazil 2014/2015 a 2024/2025. Brasília, MAPA. 133p.

Oliveira RA, Bruno NMN (2013) Start-up of horizontal anaerobic reactors with sludge blanket and fixed bed for wastewater treatment from coffee processing by wet method. Engenharia Agrícola 33(2):353-366.

Oliveira SVW, Leoneti AB, Caldo GMM, Oliveira MMB (2011) Generation of bioenergy and biofertilizer on a sustainable rural property. Biomass Bioenergy 35(7):2608-2618.

Omil F, Garrido JM, Arrojo B, Mendéz R (2003) Anaerobic filter reactor performance for the treatment of complex dairy wastewater at industrial scale. Water Research 37(17):4099-4108.

Patel P, Patel C, Madamwar D (1999) Anaerobic upflow fixed-film bioreactor for biomethanation of salty cheese whey. Applied Biochemical Biotechnology 76(3):193-201.

Patil SS, Ghasghse NV, Nashte AP, Kanase SS, Pawar RH (2012) Anaerobic digestion treatment of cheese whey for production of methane in a two stage upflow packed bed reactor. International Journal of Advanced Science, Engineering, and Technology 1(1):1-7.

Pontoni L, Panico A, Salzano E, Frunzo L, Iodice P, Pirozzi F (2015) Innovative parameters to control the efficiency of anaerobic digestion process. Chemical Engineering Transactions 43:20892094.

Prabhudessai V, Ganguly A, Mutnuri S (2013) Biochemical methane potential of agro wastes. Journal of Energy, 7p. Available: http://dx.doi.org/10.1155/2013/350731. Accessed: Feb 22, 2016.

Prazeres AR, Carvalho F, Rivas J (2012) Cheese whey management: a review. Journal of Environmental Management 110:48-68.

Raposo F, Fernández-Cegrí V, De La Rubia MA, Borja R, Béline F, Cavinato C, Demirer G, Fernández B, Fernández-Polanco M, Frigon JC, Ganesh R, Kaparaju P, Koubova J, Méndez R, Menin G, Peene A, Scherer P, Torrijos M, Uellendahl H, Wierinckm I, Dewildep V (2011) Biochemical methane potential (BMP) of solid organic substrates: evaluation of anaerobic biodegradability using data from an international interlaboratory study. Journal of Chemical Technology and Biotechnology 86(8):1088-1098.

APHA - American Public Health Association (2012) Standard Methods for the Examination of Water and Wastewater, 19 ed. Washington, DC, APHA. 2316p.

Tauseef SM, Abbasi T, Abbasi SA (2013) Energy recovery from wastewaters with high-rate anaerobic digesters. Renewable and Sustainable Energy Reviews 19:704-741.

Zhou Y, Lin; Zhang Z, Nakamoto T, Li Y, Yang Y, Utsumi M, Sugiura N (2011) Influence of substrate-to-inoculum ratio on the batch anaerobic digestion of bean curd refuse-okara under mesophilic conditions. Biomass and Bioenergy 35(7):3251-3256. 